\title{
Seasonal Variations in the Physico-chemical and Biological Characteristics of Al-Gharraf River within Al-Haay City Southern of Iraq.
}

\author{
Wisam Th. Al-Mayah ${ }^{1}$, Ali O. Shawardi ${ }^{2}$ and Rasha M. Salman ${ }^{2}$ \\ ${ }^{1:}$ Department of Soil and Water Resources, College of Agriculture, University of \\ Wasit \\ 2:Department of Basic Science, College of Dentistry, University of Wasit \\ ${ }^{2}$ Department of Biology, College of Science, University of Wasit
}

\begin{abstract}
The study reports the seasonal changes in water quality of Al-Gharraf, one of the main tributaries of the Tigris river. Monthly sampling was carried out from December 2015 till November 2016 for a year. The study location situated in the south-eastern sector of Iraq and surrounded by wide and fertile agricultural lands. Three stations were selected to. The former is located at $5 \mathrm{~km}$ before entrance of AL-Hayy City as control. The second is situated at distance $5 \mathrm{~km}$ away from the former (mid of ALHayy City) represented study area and the latter station is located at $15 \mathrm{~km}$ apart from the second one (end of AL-Hayy City). collecting samples monthly ,two samples were taken each month.

In the present study Fourteen physical and chemical parameters were analyzed based on the importance of these parameters. These Fourteen parameters are ranged as following: air temperature (16 to 32$)^{\circ} \mathrm{C}$, water temperature (11 to 26$){ }^{\circ} \mathrm{C}, \mathrm{pH}$ (7.05to 8.35), E.C. (827 to1558) $\mu \mathrm{S} / \mathrm{cm}$, salinity ( 0.54 to 0.99$) \mathrm{ppt}$, DO (7.04 to 10.38$) \mathrm{mg} / \mathrm{L}$ , BOD ( 0.90 to 7.01$) \mathrm{mg} / \mathrm{L}$,turbidity (31.0 to 177.0$) \mathrm{NTU}$, TDS (550.78 to 1108 ) $\mathrm{mg} / \mathrm{L}$, TSS (38 to 636.5 ) $\mathrm{mg} / \mathrm{L}$, T.H (275 to 520$) \mathrm{mg} / \mathrm{L}, \mathrm{Cl}^{-}(95.9$ to 213.7$) \mathrm{mg} / \mathrm{L}$, $\mathrm{NO}_{3}(15.4$ to 25.0$) \mathrm{mg} / \mathrm{L}$ and $\mathrm{PO}_{4}(0.15$ to 0.59$) \mathrm{mg} / \mathrm{L}$. The results showed that most parameters are exceeding permissible limits for Iraqi standard specifications and WHO standard for drinking.

The study results also showed that the heavy metals concentrations (cadmium and lead) were $0.002-0.089 \mathrm{ppm}$ and $0.031-0.21 \mathrm{ppm}$ respectively. Concentrations of these metals of Al-Gharraf River showed seasonal variations during the study period and they are exceeding permissible limits for Iraqi standard specifications and WHO standard for drinking.

The highest bacterial count was recorded at sit. 2 the during winter 2016, 2800 cell $/ 1 \mathrm{ml}$, whereas the lowest value was found during summer 2016, 320 cell /100ml. whereas numbers of E.coli were (230-1700) cell/10ml.
\end{abstract}

Key Words: physic - chemical and biological parameters, water quality, Al-Gharraf river. 
دراسة التغيرات الفصلية في الخصائص الفيزيائية والكيميائية والبيولوجية لمياه نهر الغراف مجلة كلية التربية

\section{ضمن مدينة الحي جنوب العرلق.}

الخلاصة:

درست التغيرات الفصلية في الخصائص الفيزيائية والكيميائية والبيولوجية للياه لتقييم نوعية مياه نهر

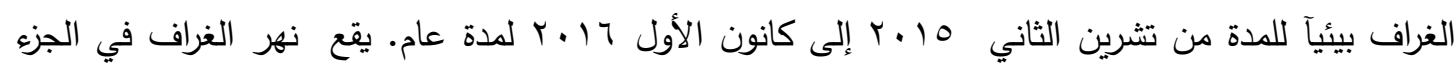

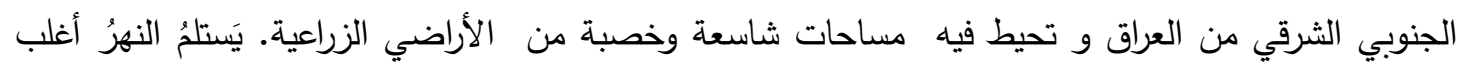

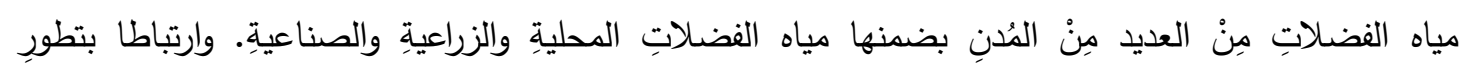
المنطقة فأن زيادة تسرب الملوثات إلى النهر كانتْ سببا للقلق في الفترة الأخيرة. تم اختيار ثلاثة محطات للاراسة ، تقع المحطة الأولى على بعد 0 كم من مدينة الحئل الحي لتكون محطة السيطرة. وتقع المحطة الثانية على بعد م كم من المحطة الأولى حيث تمثل منطقة الدراسة .أما المحطة الثالثة

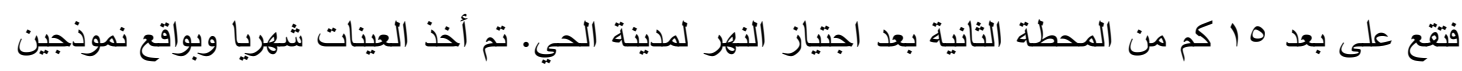
لكل شهر.

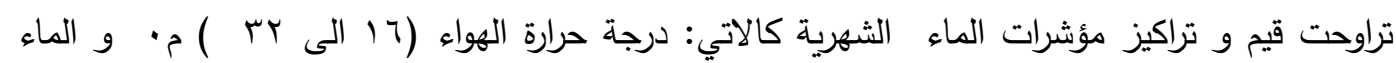

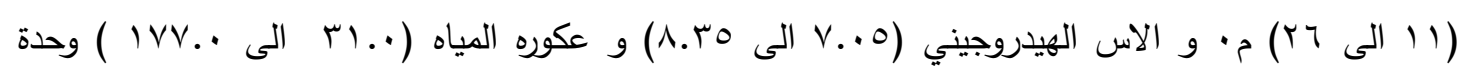

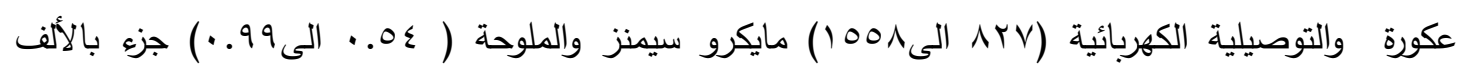

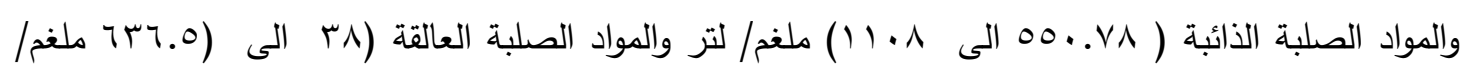

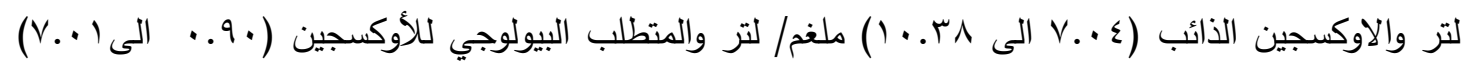

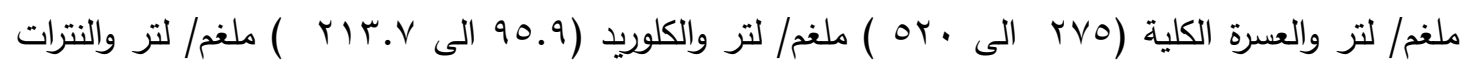

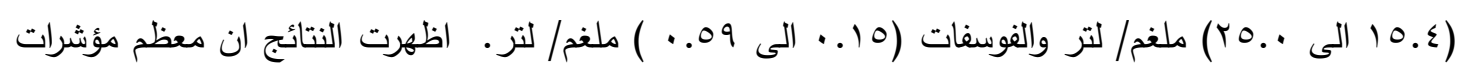

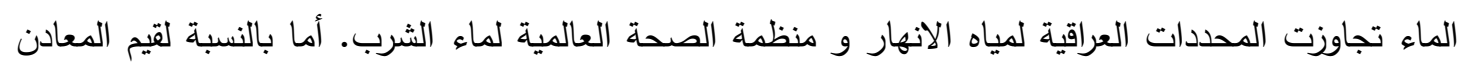

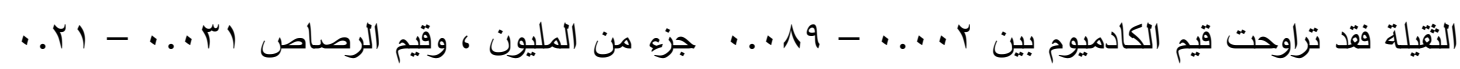
جزء من المليون. وأظهرت تراكيز المعادن المدروسة في مياه الغراف تغيرات فصلية خلا فتروت فترة الدراسة، وتجاوزت الحدود المسموح بها من قبل المحددات العراقية لنظام صيانة الأنهار .

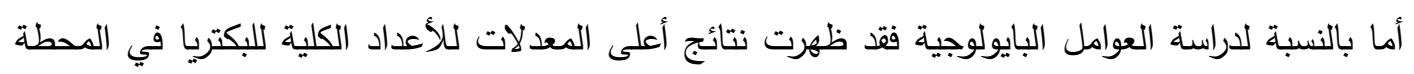

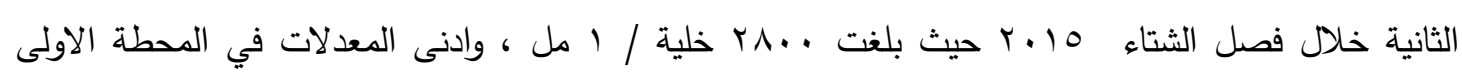

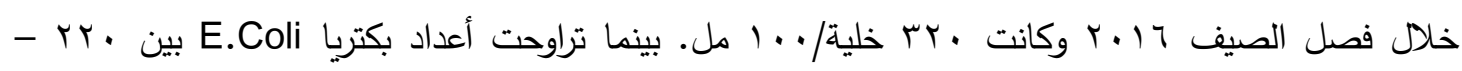
IV... 


\section{Introduction}

Rivers have always been the most important fresh water resources, and most developmental activities are still dependent upon them. Rivers play a major role in assimilating or carrying industrial and municipal waste water, manure discharge and runoff which are responsible for water river pollution[1] [2]. The degree of pollution is generally assessed by studying physical and chemical characteristics of the water bodies[3]. Iraqi inland waters witness tremendous impacts through discharges of manufacturers, agricultural and domestic sewage [4] [5]. Quite few studies were performed on Tigris River [6] [7] [8], but no work had considered Al-Gharraf canal in Al-Haay City. The present study has taken in consideration the investigation of abiotic conditions in this vital habitat on monthly basis.

\section{Material and Methods}

\subsection{Study area}

Al- Gharraf River is one of two branches of the Tigris River at Kut City, 225 km south of Baghdad City (Fig. 1). After branching from the Tigris, the Garaff flows southeast toward Al-Haay City (study area ) within Wasit Province, $220 \mathrm{~km}$ southwest of Baghdad City. The river is $230 \mathrm{~km}$ in length with a variable depth of 18 $\mathrm{m}$ at its branching point from the Tigris to $10 \mathrm{~m}$ at its junction with the Euphrates River at the marsh area near Thi Qar Province .

Figure (1) showing map of sampling location in the study area

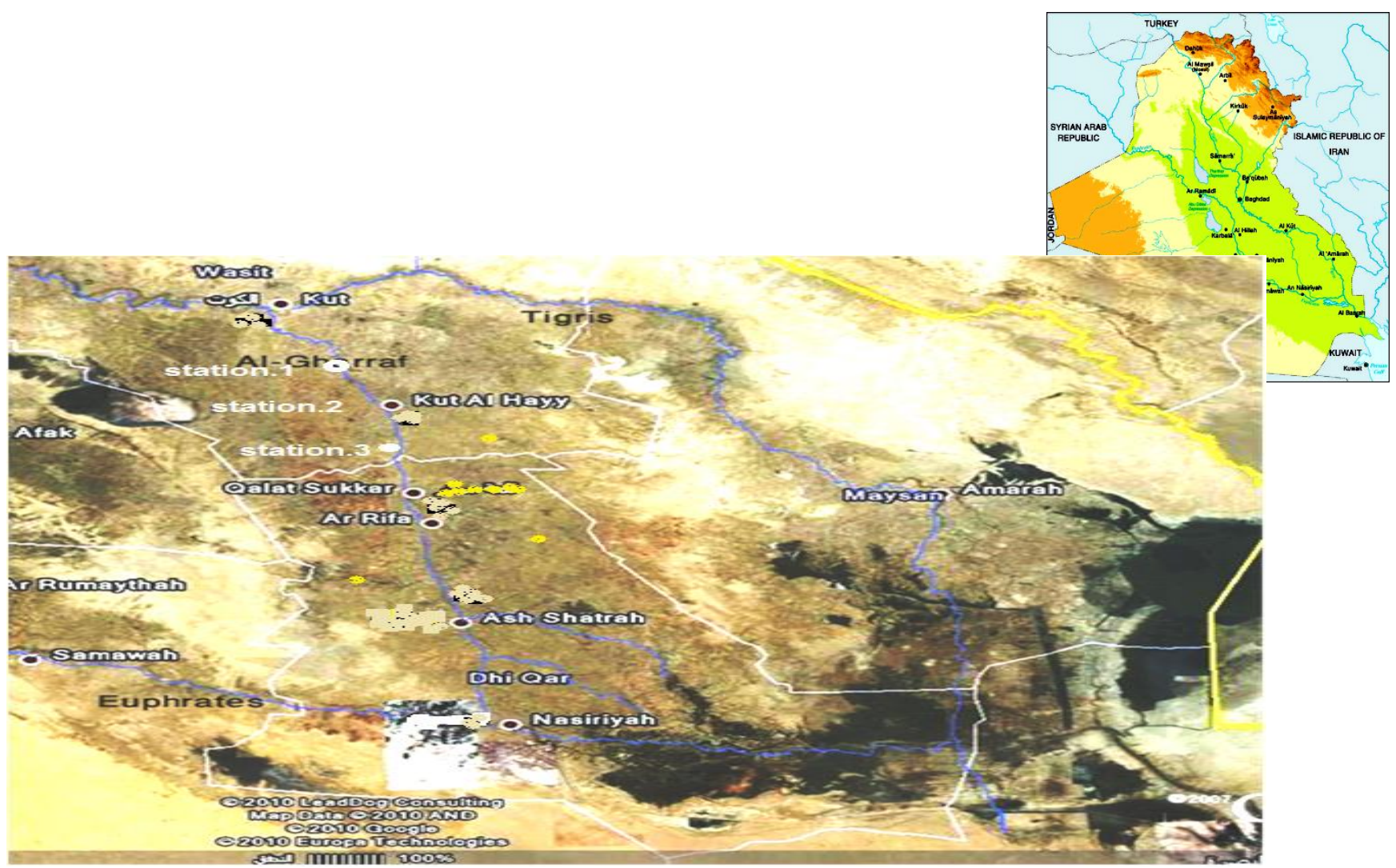




\subsection{Sampling}

Samples for physical and chemical variables were performed from three sites during period extended from the December 2015 till November 2016. Water samples were collected for physiochemical analysis using pre-washed polyethylene bottle by water sample twice before filling.

The studied physic-chemical parameters include water temperature (by using precise mercury thermometer), hydrogen ion concentration (by using $\mathrm{pH}$-meter), electrical conductivity (by using EC-meter), turbidity level (by using turbidity-meter), dissolved oxygen (titrimetric methods), biological oxygen demand (Winkler methods), nitrate, reactive phosphate (by using spectrophotometric methods), total hardness and chloride (by using titrimetric methods), were measured according to APHA[9] [10].

Heavy metals in water samples are measured using flame atomic absorption spectrophotometer (Model Pyeunicam SP9) [9].

Water sample for biological analysis E. Coli used multiple fermentation tubes or most probable number (MPN) technique are commonly used for enumeration of the bacteria [9], while total bacterial count (TBC) was carried out using the pour plate technique according to described by APHA [10].

\section{Results}

Figure (2) and Table (1), shows seasonal changes in air temperature for the three selected stations. Values ranged between $16^{\circ} \mathrm{C}$ in a station-1 during winter (2016) to $38^{\circ} \mathrm{C}$ in station-3 during summer (2016).

Figure (3) and Table (1), however, indicates seasonal variations in water temperature. The lowest value was $11^{\circ} \mathrm{C}$ in station-2 during winter (2016) and the highest $31^{\circ} \mathrm{C}$ in station-1 during summer (2016). $\quad$ Figure (4) and Table (1), shows seasonal changes in $\mathrm{pH}$. The lowest (7.05) was encountered in autumn (2015) from station-2 and the highest (8.09) was recorded in winter (2016) from station-1, but values in general were slightly alkaline direction.

Figure (5) and Table (1), Shows seasonal changes in values of Electrical conductivity. The lowest $(827 \mu \mathrm{s} / \mathrm{cm})$ was measured from station-3 in spring (2016) and the highest $(1558 \mu \mathrm{s} / \mathrm{cm})$ was observed in autumn (2015) from station-2.

Figure (6) and Table (1), shows seasonal changes in values of water salinity. The lowest (0.54 ppt) was observed in station-3 during spring (2016) and the highest (0.99 ppt) measured from station-2 in autumn (2015).

Figure (7) and Table (1), Shows seasonal changes in values of Turbidity. The lowest (31.0 NTU) was observed in station-1 in summer (2016) and the highest (177.0 NTU) was observed in winter (2016) from station-2.

Figure (8) and Table (1), Reveals seasonal variations in dissolved oxygen in selected stations Values declined during autumn (2015). The lowest $(7.04 \mathrm{mg} / \mathrm{L})$ was in summer (2016) from station-2 and the highest $(10.38 \mathrm{mg} / \mathrm{L})$ was, in general, in winter (2016) from station-1 
Figure (9) and Table (1), shows seasonal variations in values of biological oxygen demands $\left(\mathrm{BOD}_{5}\right)$. The lowest $(0.90 \mathrm{mg} / \mathrm{L})$ was recorded in spring (2016) from station1 and the highest (7.0 mg/L) was in autumn (2015) from station-2.

Figure (10) and Table (1), shows seasonal changes in total dissolved solid. The lowest $(550.78 \mathrm{mg} / \mathrm{L})$ was encountered in summer (2016) from station-3 and the highest (1108 mg/L) was recorded in autum (2015) from station-2.

Figure (11) and Table (2), shows seasonal variations in total suspended solid. The lowest $(56 \mathrm{mg} / \mathrm{L})$ was observed in summer (2016) from station-1 and the highest (938 $\mathrm{mg} / \mathrm{L}$ ) was observed in winter ( 2016 ) from station-2.

Figure (12) and Table (2), Revealed seasonal variations in values of total hardness in the selected locations. Highest value $(520 \mathrm{mg} / \mathrm{L})$ was in autumn (2015) and encountered from station-2. The lowest $(275 \mathrm{mg} / \mathrm{L})$, however, was in summer (2016) from station-1.

Figure (13) and Table (2), Shows seasonal changes in values of Chloride. The lowest $(95.9 \mathrm{mg} / \mathrm{L})$ was measured from station-1 in spring (2016) and the highest (213.7 mg/L) was observed in autumn (2015) from station-2.

Figure (14) and Table (2), Reveals seasonal variations in Nitrate. The lowest $(15.4 \mathrm{mg} / \mathrm{L})$ was in summer (2016) from station-1 and the highest $(45.00 \mathrm{mg} / \mathrm{L})$ was observed in autumn (2015) from station-2.

Figure (15) and Table (2), Shows seasonal changes in values of Reactive phosphate. The lowest $(0.15 \mathrm{mg} / \mathrm{L})$ was observed in autumn (2015) from station-1 and the highest $(0.59 \mathrm{mg} / \mathrm{L})$ was observed in autumn (2015) from station-2.

Figure (16) and Table (2), Reveals seasonal changes in values of Cadmium . The lowest $(0.002 \mathrm{ppm})$ was observed in summer (2016) from station-1 and the highest $(0.089 \mathrm{mg} / \mathrm{L})$ was observed in autumn (2015) from station-2. Figure (17) and Table (2), Shows seasonal changes in values of Lead. The lowest $(0.031 \mathrm{ppm})$ was observed in summer (2016) from station-1 and the highest $(0.21 \mathrm{ppm})$ was observed in autumn (2015) from station-2.

Figure (18) and Table (2), Reveals seasonal variations in Total Bacterial Count. The lowest 320 cell $/ 100 \mathrm{ml}$ was in summer (2016) from station-1 and the highest 7800 cell /100ml was observed in winter (2016) from station-2.

Figure (19) and Table (2), Shows seasonal changes in values of . E.coli were. The lowest 480 cell/10ml was observed in summer (2016) from station-1 and the highest 5200 cell/10ml was observed in winter (2016) from station-2 . 
العدد التاسع والعشرون

مجلة كلية التربية

Table (1): seasonal variation of physic-chemical characters of Al-Gharraf river through period study $2015-2016$

\begin{tabular}{|c|c|c|c|c|c|c|c|c|c|c|}
\hline Time & Station & $\begin{array}{l}\text { Air } \\
\text { T. } \\
\text { C }^{\circ}\end{array}$ & $\begin{array}{l}\text { Water } \\
\text { T.C }\end{array}$ & $\mathrm{PH}$ & $\begin{array}{l}\text { E.C } \\
\mu \mathrm{s} / \mathrm{cm}\end{array}$ & $\begin{array}{l}\text { Sali. } \\
\text { ppt. }\end{array}$ & $\begin{array}{l}\text { Turb. } \\
\text { NTU }\end{array}$ & $\begin{array}{l}\mathrm{DO} \\
\mathrm{mg} / \mathrm{l}\end{array}$ & $\begin{array}{l}\text { DOB5 } \\
\mathrm{mg} / 1\end{array}$ & $\begin{array}{l}\mathrm{TDS} \\
\mathrm{mg} / \mathrm{l}\end{array}$ \\
\hline \multirow{3}{*}{$\begin{array}{l}\text { Autumn } \\
2015\end{array}$} & S.1 & 30 & 24 & 7.38 & 1335 & 0.87 & 78 & 8.22 & 1.89 & 946 \\
\hline & S.2 & 30 & 26 & 7.05 & 1558 & 0.99 & 121 & 7.04 & 7.0 & 1108 \\
\hline & S.3 & 32 & 25 & 7.34 & 1339 & 0.87 & 74 & 7.61 & 4.01 & 928 \\
\hline \multirow{3}{*}{$\begin{array}{l}\text { Winter } \\
2016\end{array}$} & S.1 & 16 & 11.5 & 8.09 & 1075 & 0.69 & 161.0 & 10.38 & 2.0 & 715.9 \\
\hline & S.2 & 16 & 11 & 7.98 & 1078 & 0.70 & 177.0 & 8.36 & 5.5 & 717.9 \\
\hline & S.3 & 16 & 12.5 & 7.77 & 1062.5 & 0.69 & 163.5 & 9.57 & 2.5 & 707.7 \\
\hline \multirow{3}{*}{$\begin{array}{l}\text { Spring } \\
2016\end{array}$} & S.1 & 28 & 24 & 7.8 & 855 & 0.56 & 35 & 8.0 & 0.90 & 569.43 \\
\hline & S.2 & 29 & 23 & 7.5 & 888 & 0.58 & 67 & 7.5 & 4.5 & 591.40 \\
\hline & S.3 & 30 & 23 & 7.8 & 827 & 0.54 & 43 & 8.1 & 2.1 & 550.78 \\
\hline \multirow{3}{*}{$\begin{array}{l}\text { Summer } \\
2016\end{array}$} & S.1 & 37 & 31 & 7.8 & 1018 & 0.65 & 33 & 8.1 & 1.9 & 677.99 \\
\hline & S.2 & 37 & 29 & 7.3 & 1029 & 0.66 & 52 & 7.2 & 5.2 & 685.32 \\
\hline & S.3 & 38 & 30 & 7.2 & 1014 & 0.65 & 37 & 7.9 & 2.9 & 675.32 \\
\hline
\end{tabular}


Table (2): seasonal variation of physic-chemical and biological characters of Al-Gharraf river through

period study $2015-2016$

\begin{tabular}{|c|c|c|c|c|c|c|c|c|c|c|}
\hline Time & Station & $\begin{array}{l}\mathrm{TSS} \\
\mathrm{mg} / \mathrm{l}\end{array}$ & $\begin{array}{l}\text { T.H } \\
\mathrm{mg} / \mathrm{l}\end{array}$ & $\begin{array}{l}\mathrm{Cl}^{-} \\
\mathrm{mg} / \mathrm{l}\end{array}$ & $\begin{array}{l}\mathrm{NO} 3= \\
\mathrm{mg} / \mathrm{l}\end{array}$ & $\begin{array}{l}\mathrm{PO}_{3}^{-} \\
\mathrm{mg} / \mathrm{l}\end{array}$ & $\begin{array}{l}\text { Cd } \\
\text { ppm }\end{array}$ & $\begin{array}{l}\mathrm{Pb} \\
\mathrm{ppm}\end{array}$ & $\begin{array}{l}\text { T.B.C } \\
\text { Cell/1 } \\
\text { 00ml }\end{array}$ & $\begin{array}{l}\text { E.col } \\
i \\
\text { Cell/ } \\
10 \mathrm{ml}\end{array}$ \\
\hline \multirow{3}{*}{$\begin{array}{l}\text { Autumn } \\
2015\end{array}$} & S.1 & 738 & 430 & 159.4 & 31.09 & 0.15 & 0.023 & 0.09 & 1400 & 2900 \\
\hline & S. 2 & 890 & 520 & 213.7 & 45.00 & 0.59 & 0.089 & 0.21 & 2150 & 3600 \\
\hline & S.3 & 820 & 437.5 & 193.6 & 35.69 & 0.31 & 0.081 & 0.19 & 3200 & 2500 \\
\hline \multirow{3}{*}{$\begin{array}{l}\text { Winter } \\
2016\end{array}$} & S.1 & 887 & 314 & 154.9 & 20.12 & 0.19 & 0.009 & 0.073 & 2700 & 3400 \\
\hline & S.2 & 938 & 412 & 198.5 & 32.45 & 0.23 & 0.013 & 0.096 & 7800 & 5200 \\
\hline & S.3 & 908 & 392 & 180.7 & 25.62 & 0.2 & 0.011 & 0.089 & 1350 & 3800 \\
\hline \multirow{3}{*}{$\begin{array}{l}\text { Spring } \\
2016\end{array}$} & S.1 & 165 & 310.4 & 89.02 & 16.1 & 0.32 & 0.004 & 0.033 & 1500 & 2300 \\
\hline & S.2 & 196 & 388 & 153 & 20.0 & 0.43 & 0.007 & 0.041 & 3900 & 4200 \\
\hline & S.3 & 185 & 329.8 & 111.5 & 16.0 & 0.38 & 0.005 & 0.039 & 2800 & 2100 \\
\hline \multirow{3}{*}{$\begin{array}{l}\text { Summe } \\
\text { r } \\
2016\end{array}$} & S.1 & 56 & 275 & 95.9 & 15.4 & 0.33 & 0.002 & 0.031 & 320 & 480 \\
\hline & S.2 & 86 & 335 & 138 & 28.2 & 0.45 & 0.006 & 0.037 & 1500 & 2600 \\
\hline & S.3 & 87 & 360 & 105 & 21.7 & 0.38 & 0.005 & 0.035 & 980 & 1400 \\
\hline
\end{tabular}

Table (3): Comparison between some water quality parameters of Al-Gharraf river with the Iraqi and International standards.

\begin{tabular}{|c|c|c|c|}
\hline Parameter & $\begin{array}{l}\text { WHO } \\
(2004)\end{array}$ & $\begin{array}{c}\text { EEC 464/76 } \\
\text { (Tebbutt, 1998 ) }\end{array}$ & $\begin{array}{c}\text { Iraqi standards } \\
(\uparrow \ldots l)\end{array}$ \\
\hline $\mathrm{pH}$ & $6.5-8.5$ & $6.5-8.5$ & $6.5-8.5$ \\
\hline TDS $\mathrm{mg} / \mathrm{L}$ & $500-1500$ & $500-1500$ & 1000 \\
\hline Turbidity NTU & $0-50$ & $0-25$ & 25 \\
\hline DO $\mathrm{mg} / \mathrm{L}$ & $>5$ & $>5$ & $>5$ \\
\hline BOD5 $\mathrm{mg} / \mathrm{L}$ & $>3$ & $>5$ & $>3$ \\
\hline T.H mg/L & $100-500$ & $100-500$ & - \\
\hline $\mathrm{Cl}^{-} \mathrm{mg} / \mathrm{L}$ & 200 & $200-600$ & 200 \\
\hline $\mathrm{NO}_{3}^{-} \mathrm{mg} / \mathrm{L}$ & $0-45$ & $0-40$ & $25-50$ \\
\hline Cd ppm & $\because \cdots$ & $\because \cdots 0$ & $\because \cdots 0$ \\
\hline $\mathrm{Pb}$ ppm & $\because \cdot 1$ & $\because .0$ & $\because \cdot 1$ \\
\hline
\end{tabular}



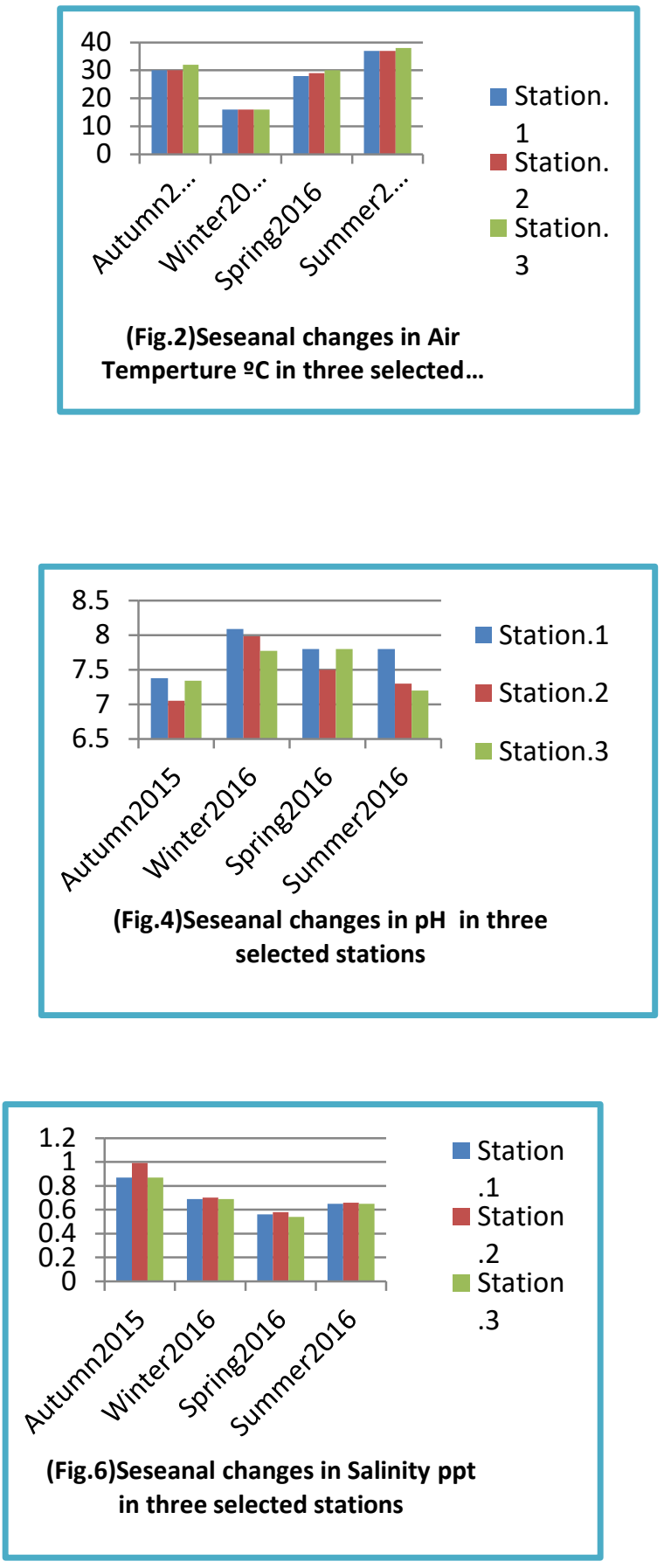
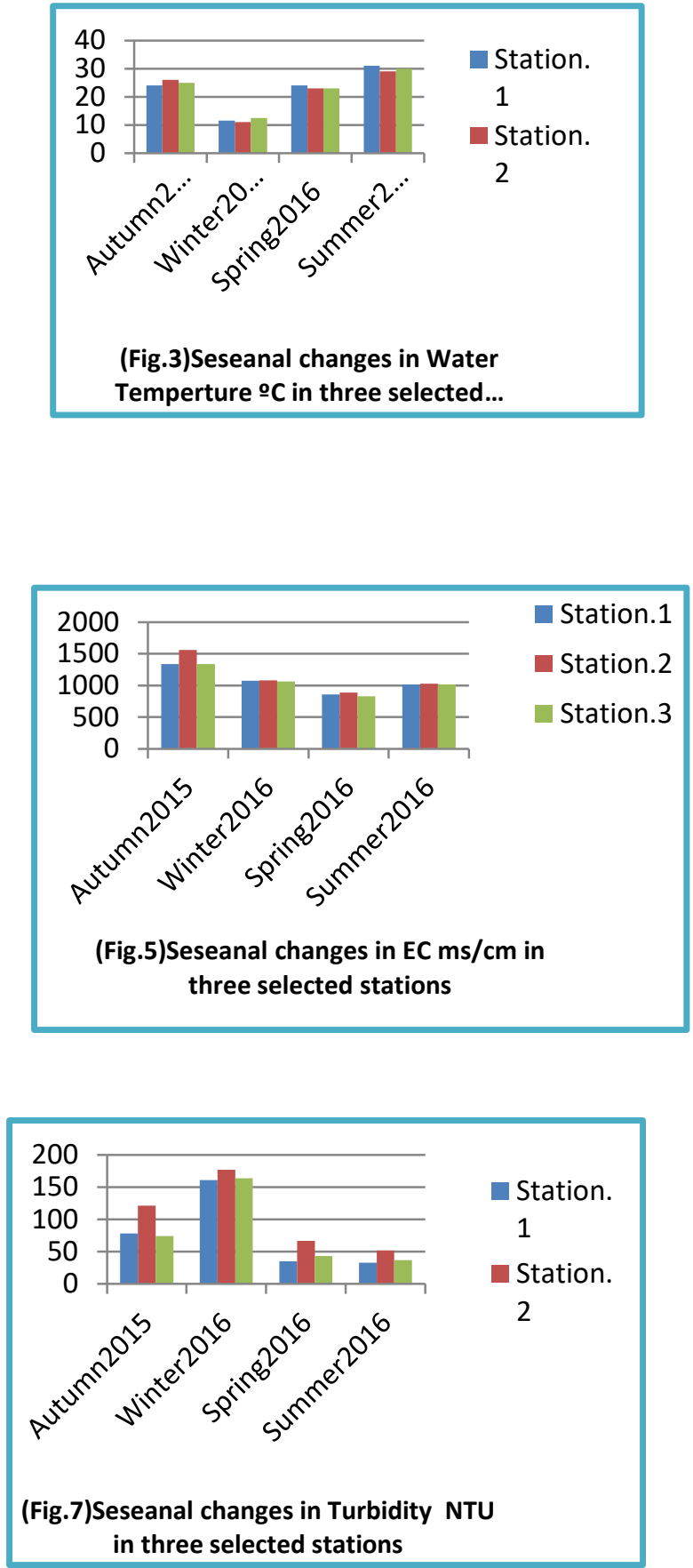

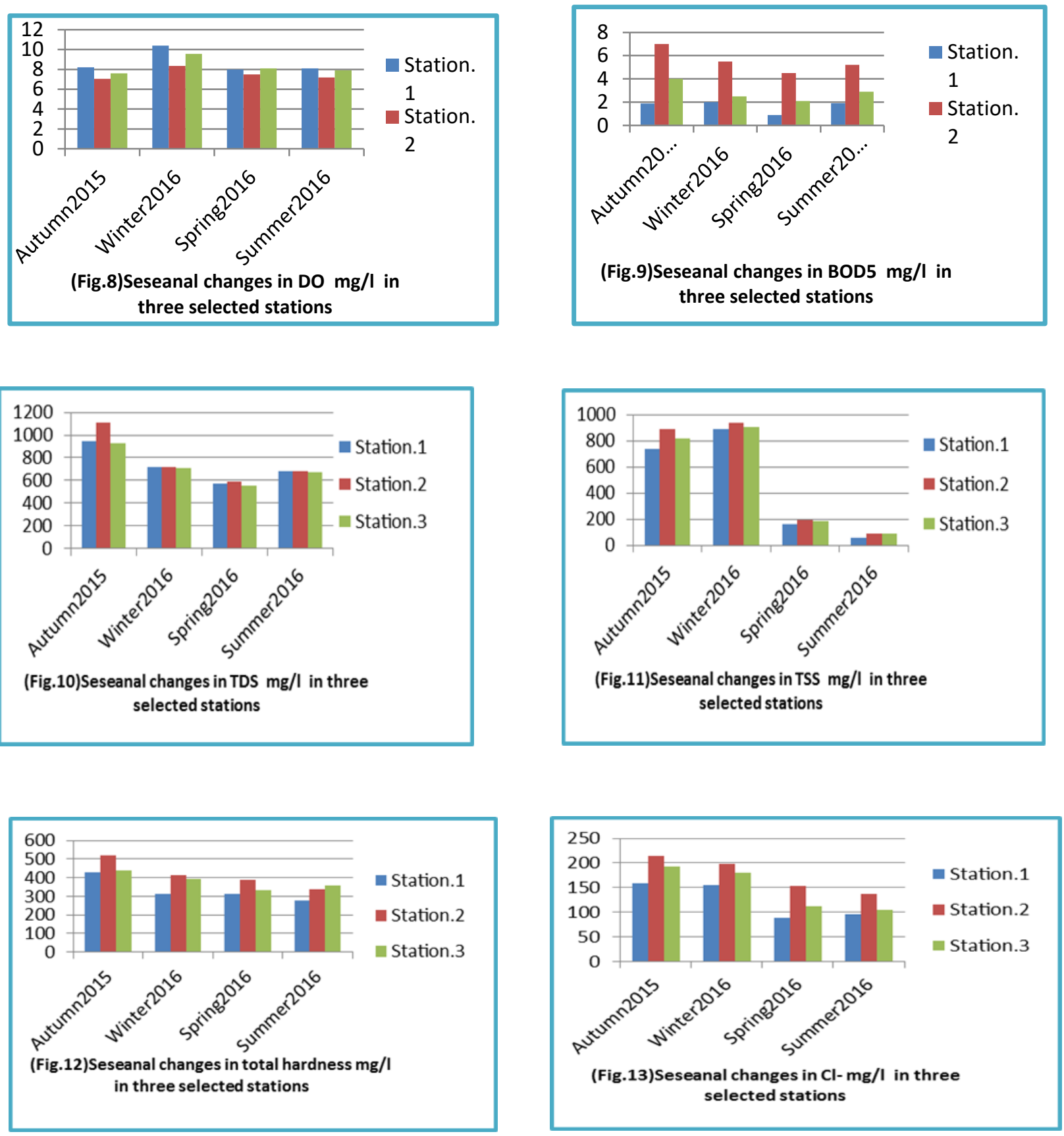

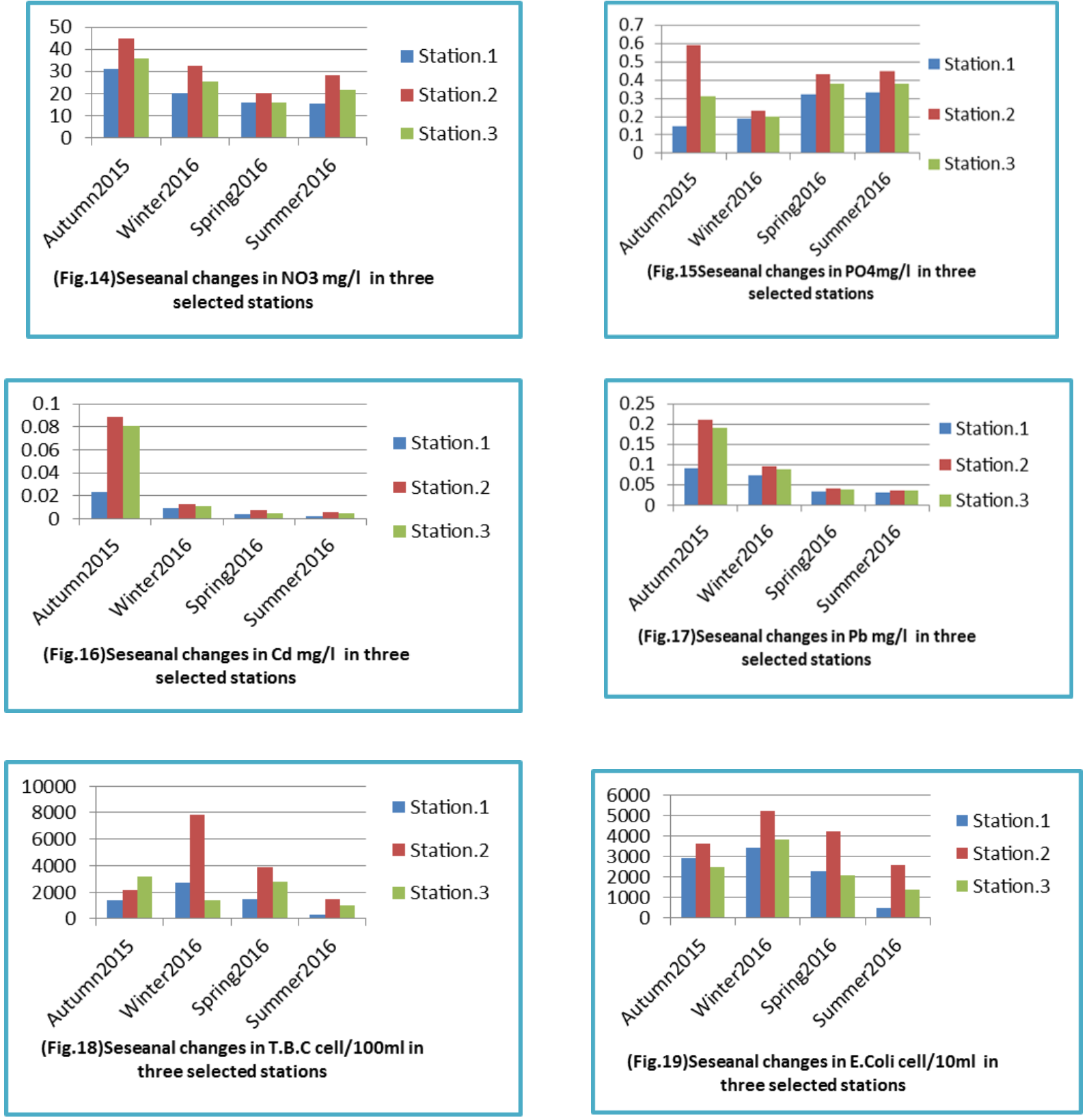


\section{Discussion}

Air and water temperature is an important factor in any aquatic environments affecting on biological processes, in this study it was ranged between 16 to $38 \circ \mathrm{C}$ and 11 to $31^{\circ} \mathrm{C}$ respectively. This result was similar to previous studies done by [11] [12].

The $\mathrm{pH}$ value of AL-Gharraf River in study sites during of most studied period was alkaline side above 7, and this result agreed with [13], they reported that Iraqi inland water is regarded to be on the alkaline side of neutrality, reflecting geological formations of the area and the results are agree with the finding that recorded by [14] [15]. Electrical conductivity used as an indicator of water quality based on total dissolved salts [16]. The increase of EC values at station two reflects the strong effect of domestic sewage effluent discharge at this area. Also, EC values recorded in the present work is coincided with findings of [17] [18]. The study also revealed monthly changes in salinity, with notable increase during summer months due to evaporation [19]. The presence of agricultural drainage systems namely, Kut, Al-Muafakiah and AL-Haay may contribute in rising salinity as well[20]. Water turbidity is caused by suspended matter such as clay, silt and planktons also turbidity degree of River water is an approximate measure of the intensity of the pollution [20]. This result was similar to previous studies done by [21] [22]. Oxygen content of water is one of the important factors, and it is very necessary for all living organisms [23].The study finding coincided with other authors [24] [25] [26] on Iraqi inland waters mainly Tigris. Low concentration of DO recorded from station- 2 may relate to organic wastes discharged from Al-Haay City. Generally, the DO at most stations of canal water was within normal guideline values cited by [27] for the protection of aquatic life.

The biological oxygen demand is defined as the quantity of DO which is able to oxidize the organic components in the water with the assistance of microorganisms under defined experimental conditions [28] . Generally, results indicate increasing levels of BOD, in particular at station-2 during the November and October, this may be due to decomposition of organic matters run directly to the river with domestic sewage. These results were slightly higher than that reported by [29] [30] at the same river. Values of total hardness in the selected stations exceeded $520 \mathrm{mg} / \mathrm{L}$ as $\mathrm{CaCO} 3$. This indicates that waters are very hard according to [31]. Increase in hardness values was found to coincide with rise in salinity [32] [33]. The results of total hardness are agreed with those of [34] [35]. Chloride is a natural substance present in all portable water as well as sewage effluents as metallic salt. Generally high concentration of chloride indicates to organic pollution in the water [36]. This result was similar to previous studies done by [37] [38]. Total dissolved solids (TDS) is the term used to describe the inorganic salts and small amounts of organic matter present in solution in water [39]. These results were slightly lower than that reported by [40] [41] at the same river. Total suspended solids are considered to be one of the major pollutants that contributes to the deterioration of water quality, contributing to higher costs for water treatment, decreases in fish resources, and the general aesthetics of the water [42], TSS values recorded in the present work is coincided with findings of [43] [44] Nitrate is the stable form of combined nitrogen and it is an important factor which might limit growth of phytoplankton [45]. The results of nitrate are agreed with those of [46] [47] Phosphorus is essential to the growth of algae and other biological organisms. The reactive phosphate concentration in studied river was ranged between 0.15 to $0.5 \mathrm{mg} / \mathrm{l}$. The high concentration of phosphate may be due to sewage water 
effluent and fertilizer application in surrounding agricultural area. This result was close to that reported by [48]. Cd can enter the environment from various anthropogenic sources such as by-products from zinc refining, coal combustion, mine waste, electroplating processes, iron and steel production, and pesticides[49].The increase of the concentration of Cd during autumn season and decrease during summer due to increased discharge of domestic sewage especially at station 2 and using of fertilizer and pesticides that is added to agricultural lands [50]. Lead is one of the very toxic heavy metals that not only accumulate in individual but also have the ability to affect the entire food chain and disrupt the health system of human beings, animals and phytoplankton [51]. The recorded concentrations of $\mathrm{Pb}$ in Al-Gharraf River in all the stations as a result of the passage of the river through agricultural lands that used different chemicals that contains $\mathrm{Pb}$ [52]. The total bacterial includes all of the bacterial species that are capable of growing in or on a nutrient rich solid agar medium [53]. High numbers of bacterial level of the Al-Gharraf River due to receiving the large amounts of sewage especially in Al-Hayy city, as wall as increase the agricultural activities have led to increase bacteria number in the waters of the river [54]. The presence of E.coli bacteria in aquatic environments indicates that the water has been contaminated with the fecal material of man or other animals[55]. In this study fecal indicator bacteria abundance were measured in samples collected in river located in Al-Haay city. Results showed that this river which flowing through urban areas was more contaminated than those rivers which flowing through agricultural areas [37].

\section{Conclusions}

The results of the study revealed that the river is not suitable for use as drinking water without elaborate treatment, poor for aquatic life protection and fair for irrigation. Also the results revealed that most water quality parameters were excess the Iraqi standards, and WHO standards for the raw water. The shortage of water in the river and runoff of the domestic sewage impacted negatively on the quality of water.

\section{References}

1.Toman, M.J.( 2009). Physico - Chemical Characteristics and Seasonal Changes of plankton communities in a reservoir. Lakes and reservoirs research and management. 2(1\&2); 71 - 76.

2. Kumar, Rita. N., Rajal Solanki and Nirmal Kumar J.I (2011). An Assessment of Seasonal Variation and Water Quality Index of Sabarmati River and Kharicut Canal at Ahmedabad, Gujarat Electronic Journal of Environment, Agriculture and Food Chemistry 10 (8), 2771-2782

3. Duran, Mustafa and Menderes Suicmez (2007). Utilization of both benthic macroinvertebrates and physiochemical parameters for evaluating ; water quality of the stream Cekerek (Tokat Turkey).J.Environ.Biol 28,231-236.

4. Wrobel, L. C. and Brebbia, C. A. (1994). Modeling measuring and production in : water pollution Wessex Institute of technology. U. K. PP.51.

5. Klerks, P. L. and Lentz, S. A. (1998). Resistance to lead and zinc in the western Mosquito fish, Gambusia affinis Inhabiting contaminated bayon tre pagnier, Ecotoxicology, $7: 11-17$.

6. Al-Lami, A. A. ; and Th. I. Kassim ; A. W. Sabri and K. A. Rasheed (1996). The ecological effects of Diyala river on Tigris River. I. Limnology. J. Coll. Educ. for women. Univ. Baghdad, 7(1):84-92.

7. Al-Saadi, H. A.; Al-Lami, A. A.; Kassim, T. I. (1999) studies to ecological characteristics of upper Tigris and Euphrates Rivers and its correlation with fishery progress in Iraq. J. Environmental and sustainable progress researches, Vol.2, No.2- 1420. p. 24-31.

8. Al-Rubaee, M. A. J. (1997) Ecological study to Ethem river and its impact on Tigris. MSc thesis; Baghdad University. (in Arabic)

9. APHA(1998). Standard methods for the examination of water and waste water, 20th ed. 
10. APHA,AWWA and WFF (2005) Standard Methods for the Examination of Water and wastewater, 21th ed., edited by Eaton, A. D. ; L. S. Clesceri; E. W. Rice, and A. E. Greenberg. American Water Work Association and Water Environment Federation,USA.

11. Sabri, A. W. ; Maulood, B. K. and Sulaiman, N. E. (1989). Limnological studies on river Tigris : Some physical and chemical characters. J. Biol. Sci. Res., 20 (3) : 565-579.

12. Al-Rubaee, M. A. J. (1997) Ecological study to Ethem river and its impact on Tigris. MSc thesis; Baghdad University. (in Arabic)

13. Maulood B K, Hinton G C F, and Al-Dosky H S. 1980. A study on the blue green algal flora of Arbil province, Iraq. Zanco Sci. J. Univ. Sulaimaniyah, Iraq, 6:67-90.

14. Al-Lami,A.A.; Jaweir, H. J. and Nashaat, M. R. (1998). Benthic invertebrates of the river Euphrates upstream and downstream sectors of Al-Qadisia Dam, Iraq. Reg. Riv. 14 (4): 383-390.

15. Al-Obaidi, G. S. A. (2006). A Study of phytoplankton community in Abu Zirig marsh, Southern Iraq. MSc Thesis, University of Baghdad, Iraq.

16. Rasheed R O. (1994). A limnological study on some water systems in Erbil province. Iraq. M.Sc. Thesis. Univ. of Salahaddin-Erbil, Iraq.

17. Al-Saadi, H. A. ; Hadi, R. A. M. and Al-Lami, A. A. (1989). Limnogical studies on some marsh areas in southern Iraq . Limnogica, 20 (2).

18. Hashim, N. N. (2010). Investigation of Cadmium and Mercury in Water,Sediments and Some Benthic Invertebrates at section of Tigris River in Baghdad City.Ms.C. Thesis, college of Science, Baghdad University: 125 PP.

19. Afzal,S; Ahmad, I.;Younas, M.;Zahyd, M.; Khan,M.; Ijaz,A.andAli, K. (2000). Study of water quality of Hydiadrain , India. Pakistan. Environ-int. 29(1-2):87-96.

20. Siliem, T. A. E. (1995): primary productivity of the Nile in barrage area. Menofiya J. Agric. Res.20 (4): 16871701.

20. Al-Helaly, S. H. E. (2010). An investigation of some heavy metals in water, sediment and some biota of AlGharraf River, south of Iraq. M.Sc. Thesis. College of science, University of Baghdad.

21. Abed Al-Razzaq H. T.(2011) Effect of Domestic Wastewater from Pumping Station of Al-Kadimiya on Ecological Properties of Tigris River. MSc. Thesis Collage of science, Baghdad university.

22. World Health Organization (WHO),(2006). Guidelines for the safe use of wastewater, excreta and gray water: Wastewater use in agriculture. Volume II. France: 222pp.

23. Al- Nimma, B. A. B. (1982). A study on the limnology of the Tigris and Euphrates rivers , M. Sci. Thesis Salahddin Univ. , Iraq.

24. Al-Saadi, H. A.; Al-Lami, A. A.; Kassim, T. I. (1999) studies to ecological characteristics of upper Tigris and Euphrates Rivers and its correlation with fishery progress in Iraq. J. Environmental and sustainable progress researches, Vol.2, No.2- 1420. p. 24-31.

25. Attee, R. S. (2004) water characteristics in the Shatt Al-Arab river and the main drainage. Ph.D thesis, Basrah University. pp-128.

26. USEPA, (1999): National recommended water quality criteria - correction -United State Environmental Protection Agency EPA 822- Z-99-001;25p

27. Sawyer, C.N. and McCarthy, P.L. (1978). Chemistry for environmental engineering. $3^{\text {rd }}$.Ed. McGraw-Hill Book Company. Singapore. 532pp.

28. Fahad, K. K. (2005). Ecological survey for southern sector of Al-Garaf River, southern Iraq. Ph. D. Thesis. Collage of Agriculture, University of Basrah.

29-. Sadek and Kamel (2007).Seasonal variations in abiotic ecological conditions in Al-Garaf canal one of the main Tigris branches at Thi Qar province.J. Coll. Sci. Univ. Basrah :3-6

30. Lind, O. T. (1979). Hand book of common methods in limnology. 2nd .Ed. London (109) pp .

31. Al-Gaffily, A. A. K. (1992) Study of algae in Razzaza lake. MSc thesis. Baghdad University. p-102. (in Arabic)

32. Hassan, F. M. (1997). A limnological study on Hilla river . Al- Mustainsiria J. Sci, 8 (1) : 22-30.

33. AL-Saadi,H.A.;AL-Tamimi,A.N.and AL-Ghafily,A.A.(1998) on thelimnological features of Razzazah Lake, Iraq . Mutah J.for Research and Studies .3(2):111-127. 
34. Al-Nimrawee, A.M.R. (2005). The biodiversity of zooplankton and benthos invertebrates in Tigris and Euphrates River, Central Iraq. Ph. D. Thesis. Collage of Science, University of Baghdad.

35. Ajit M. Kalwale and Padmakar A. Savale (2012). Determination of Physico-Chemical Parameters of Deoli Bhorus Dam water, Advances in Applied Science Research, 3 (1):273-279.

36. Al-Kuraishi,R.A.(2011). A study of the effects of some ecological factors of Kut Dam on the Benthic Invertebrates of River Tigris. MSc. Thesis. Collage of science, Baghdad university.

37. AL-Mayah, W. Th. (2013). Effect of domestic sewage on water quality of Al-Gharraf River in Al-Haay city .M.Sc. Thesis. College of Science, University of Baghdad, Iraq. 123 pp.

38. Joseph, N. C.; Eddy, A. O.; Elijah, J. P. and Ikechukwu, O. N. E. (2011). Physicochemical evaluation of the effects of total suspended solids, total dissolved solids and total hardness concentrations on the water samples in Nsukka Town, Enugu State of Nigeria. Amr.J. Sci. 7 (5):827-836.

39. AL-Zamili, H.F. (2007). Monthly variations of some environmental factors of AL-Gharraf River, J. of Dhi Qar, 3 (3) :17-2

40. Kathy,M.T.(2008). Study of some physical and chemical properties of water and sediments of AL-Gharraf River, M.Sc.Thesis Collage of science, The-Qar University,79p. (In Arabic).

41. Bilotta,G.S.,Brazier,R.E.,2008.Understanding the influence of suspended solids on waterqualityandaquaticbiota.WaterRes.42(3),2849-2861.

42. Al-Saadi, H. A. ; Hadi, R. A. M. and Al-Lami, A. A. (1989). Limnogical studies on some marsh areas in southern Iraq . Limnogica, 20 (2).

43. Al-Fatlawy, Y.F.K. (2007). Study the Drinking Water Quality of Some Baghdad Drinking Water Treatment Stations. Ph. D. Thesis. Universityof Baghdad. (In Arabic).

44. Ali, L. A. (2007). A study of macroinvertebrates community in the middle sector of Greater Zab River, Iraq. Ph.D. Thesis. Univ. of Baghdad. Iraq.

45. Al-Lami,A.A. and Kassim, T. I. And Dulymi, A.A. (1999).Alimnological study on Tigris River. Iraq . The Sci. J, IAEC. 1:83.98.

46. Al-Ani, S. A. (2002). Effect of Diyala River on the chemical and physical propereties of Tigris River in southoren Baghdad region. Ph.D. Thesis,college of Edu. Ibn- Al- Haithem, University of Baghdad: 170 PP.

47. Maulood, B. K. ; Al-Azzawi, M. N. and Saadalla, H. A. (1994). An ecological study on the Tigris river pre and after crossing Baghdad. J. Coll. Educ. Univ. Baghdad 5 (1) : 43-50.

48. Al-Temymy, A.F.SH. (2004). A microbiological and ecological study for the Tigris and Dyalah at the south of Iraq .MSc. Thesis, College of Science, Baghdad University. (In Arabic).

49. USEPA (United States Environmental Protection Agency) (2011). Protocol for Developing Pathogen TMDLs, EPA 841-R-00-002.

50. Ogunfowokan, A.O.; Oyekunle, J.A.O.; Olutona, G.O.; Atoyebi, A.O. and Lawal, A.(2013).Speciation study of heavy metals in water and sediments from Asunle River of the Obafemi Awolowo University, Ile-Ife, Nigeria. Int. J. Environ. Prot. Vol. 3 (3): 6-16.

51. David, T.W.; Myint, Th. M. and Sein, T. (2003). Lead removal from industrial waters by water hyacinth. AU J. T., 6(4):187-192.

52. Fahad, K. K. (2005). Ecological survey for southern sector of Al-Garaf River, southern Iraq. Ph. D. Thesis. Collage of Agriculture, University of Basrah.

53. WHO (World Health Organization) (2004). Guidelines for Drinking-water Quality 2004 (3rd Ed.). Geneva: World Health Organization.

54. Adam, S. H.M. and Allaahmed, A. A. A.(2012). Effect of antimicrobial properties of pepper fruits on some spoilage organism of sudanese wet-salted fermented fish (fassiekh) product. World's Vet. J. 2(1): 05-10.

55. Shivayogimath, C.B; Kalburgi, P.B; Deshannavar, U.B. and Virupakshaiah, D.B.M.(2012).Water quality evaluation of River Ghataprabha, India.I Res. J. Environ. Sci.Vol. 1(1):12-18 